\title{
STUDY ON ASSESSMENT OF BIOMEDICAL WASTE MANAGEMENT PRACTICES IN A TERTIARY CARE HOSPITAL IN A DISTRICT OF ASSAM
}

\author{
Alpana Priya Rabha1, Pankaj Bayan², Arpita Nath³, Rupali Baruah ${ }^{4}$ \\ ${ }_{1}^{1}$ Assistant Professor, Department of Community Medicine, Assam Medical College, Dibrugarh, Assam, India. \\ ${ }^{2}$ Registrar, Department of Community Medicine, Assam Medical College, Dibrugarh, Assam, India. \\ ${ }^{3}$ Demonstrator, Department of Community Medicine, Assam Medical College, Dibrugarh, Assam, India. \\ ${ }_{4}^{4}$ Professor and HOD, Department of Community Medicine, Assam Medical College, Dibrugarh, Assam, India.
}

ABSTRACT

\section{BACKGROUND}

Biomedical waste management is an important issue for public health. Biomedical waste not only causes health hazard to medical personnel, but also is an important threat to the public and to the environment.

The objective of the study is to assess the biomedical waste management practices and to evaluate the knowledge regarding biomedical waste management practices among healthcare workers.

\section{MATERIALS AND METHODS}

This cross-sectional study was conducted in Assam Medical College and Hospital, Dibrugarh, Assam during April '17 - Sept '17. Using purposive sampling method, a total of 138 healthcare personnel were selected, with three groups of 46 each of doctors, nurses and grade IV workers working in the hospital. Data was collected using a pre-tested, structured questionnaire. Data compilation and analysis was done by using Microsoft Excel 2007.

\section{RESULTS}

The study has found that the highest numbers of blue/ white bins (96.2\%) and yellow bins (90.7\%) were correctly located. Red bags were available sufficiently and only 90 (7\%) (yellow bags) were available. Collection, separation, storage and transportation of all the bags in the hospitals were done $100 \%$ daily. The usage of personal protective equipment was also found to be satisfactory, but all the personal protective equipment was not available $100 \%$. The training of the health care workers was also found to be inadequate in the hospital. The knowledge and practices of biomedical waste management among the healthcare workers were also found to be inadequate in the hospital. Hepatitis B vaccination status among the health care workers was also found to be inadequate.

\section{CONCLUSION}

The study concluded that the biomedical waste management practices among the healthcare workers/ personnel was found to be average. There must be proper implementation of management policy as well as training and immunisation among the health workers in the health facilities.

\section{KEY WORDS}

Biomedical Waste, Health Hazard, Infected Waste.

HOW TO CITE THIS ARTICLE: Rabha AP, Bayan P, Nath A, et al. Study on assessment of biomedical waste management practices in a tertiary care hospital in a district of Assam. J. Evolution Med. Dent. Sci. 2018;7(33):3710-3714, D0I: $10.14260 /$ jemds/2018/833

\section{BACKGROUND}

Biomedical Waste (BMW) is defined as any waste, which is generated during the diagnosis, treatment or immunisation of human beings or animals or in research activities pertaining thereto or in the production or testing of biological products. ${ }^{1}$ Biomedical waste management nowadays has become an important health issue to not only the hospital, but also to the environment. Because of lack of awareness or due to less concern on these problems, the biomedical waste management problems are still in nuisance state. After implementation of Biomedical Waste (Management and Handling) Rules in 1998 by Govt. of India, it became an

'Financial or Other Competing Interest': None.

Submission 07-07-2018, Peer Review 30-07-2018,

Acceptance 06-08-2018, Published 13-08-2018.

Corresponding Author:

Dr. Alpana Priya Rabha,

Department of Community Medicine,

Assam Medical College,

Dibrugarh, Assam, India.

E-mail: alporabha@gmail.com

DOI: $10.14260 /$ jemds $/ 2018 / 833$

(c) $($ ) $\$$ important health issue to the hospital staff and general public. Each day hospitals generate large volumes of waste as a by-product of a variety of health services and procedures carried out in different ways and activities. It is estimated that about 10 to 15 percent of health care waste is infected

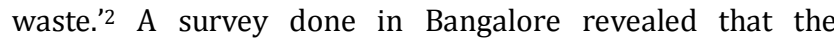
quantity of solid waste generated in hospitals and nursing homes generally varies from $1 / 2$ to $4 \mathrm{~kg}$ per bed per day in Govt. Hospitals, $1 / 2$ to $2 \mathrm{~kg}$ per bed per day in private hospitals and $1 / 2$ to $1 \mathrm{~kg}$ per bed per day in nursing homes. ${ }^{3}$ More than 2 billion people worldwide have evidence of past or current HBV infection and every year 3 - 4 million people are infected with the hepatitis $\mathrm{C}$ virus. Throughout the world, an estimated 16 billion injections are administered annually. ${ }^{3}$ Risks in hospitals or health care settings are very high. Medical-related waste is disposed off illegally into the garbage and into the sewers (NYDEC 1998). 4

According to the MRD report, the hospital has average daily attendant about 1782 and average bed occupancy of 91.74 as well as average daily death of 8.82 and average daily admission of 184 . The wastes generated from the hospitals were found to be $0.5775 \mathrm{kgs} /$ day. ${ }^{5}$ This is comparatively less 
than as suggested by previous studies, which suggests that most hospitals in India generate 1 - 2 kgs per day. ${ }^{6}$ According to WHO $85 \%$ of hospital waste is non-hazardous, $10 \%$ infective and remaining $5 \%$ non-infective but hazardous. ${ }^{4}$ Taking great importance on biomedical waste management and this type of study was not done before. The present study had been conducted with the aim to assess the biomedical waste management practices and to evaluate the knowledge on BMW management practices among health care workers at Tertiary Care Hospital in Dibrugarh town of Assam.

\section{MATERIALS AND METHODS}

This cross-sectional study was carried out in a tertiary care hospital of Assam during April '17 - Sep '2017. 138 health care personnel working in the hospital were included for the study. Using purposive sampling method, a total of 138 health care personnel was selected from the sampling frame, which consisted of 3 groups with 46 each of doctors, nurses and grade IV workers/ waste handlers. A pilot study was carried out before the study had been undertaken. The data had been collected using the checklist and pre-designed pretested structured questionnaire and it was collected simultaneously from various wards, outpatient departments, laboratory, ICU, OT, casualty department by the primary investigator under the supervision of faculty of Department of Community Medicine. Inclusion criteria were individuals selected by sampling method with work experience of more than one month in the current institution. Individuals who were not willing to participate in the study were excluded. Informed consent was taken from the study participants and ethical clearance was taken from the Institutional Ethical Committee.

\section{Statistical Analysis}

The responses to the questions were coded and entered into Microsoft Excel 2007. Data was analysed and results were expressed as numbers and percentages.

\section{RESULTS}

\begin{tabular}{|c|c|c|c|c|c|}
\hline 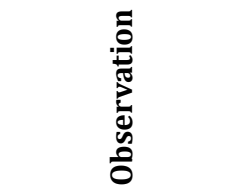 & 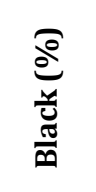 & $\frac{\underbrace{a}}{3}$ & $\underbrace{\mathfrak{d}}_{\substack{0 \\
0}}$ & 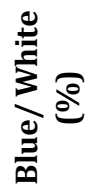 & 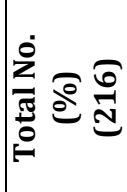 \\
\hline $\begin{array}{l}\text { Located at right } \\
\text { place }\end{array}$ & $\begin{array}{c}51 \\
(94.4)\end{array}$ & $\begin{array}{c}49 \\
(90.7)\end{array}$ & $\begin{array}{c}54 \\
(100)\end{array}$ & $\begin{array}{c}52 \\
(96.2)\end{array}$ & $\begin{array}{c}206 \\
(95.37)\end{array}$ \\
\hline Placed on stand & $\begin{array}{c}4 \\
(7.4) \\
\end{array}$ & $\begin{array}{c}3 \\
(5.5) \\
\end{array}$ & 0 & $\begin{array}{c}7 \\
(12.9) \\
\end{array}$ & $\begin{array}{c}14 \\
(6.4) \\
\end{array}$ \\
\hline $\begin{array}{c}\text { Contains waste as } \\
\text { in schedule } 1 \\
\end{array}$ & $\begin{array}{c}35 \\
(64.8) \\
\end{array}$ & $\begin{array}{c}46 \\
(85.1) \\
\end{array}$ & $\begin{array}{c}41 \\
(75.9) \\
\end{array}$ & $\begin{array}{c}45 \\
(83.3) \\
\end{array}$ & $\begin{array}{c}167 \\
(77.31) \\
\end{array}$ \\
\hline $\begin{array}{l}\text { Respective bins } \\
\text { fitted with closed } \\
\text { fitting cover }\end{array}$ & $\begin{array}{c}4 \\
(7.4)\end{array}$ & 0 & $\begin{array}{c}1 \\
(1.8)\end{array}$ & $1(1.8)$ & $\begin{array}{c}6 \\
(2.77)\end{array}$ \\
\hline $\begin{array}{l}\text { Labelling done } \\
\text { properly }\end{array}$ & $\begin{array}{c}50 \\
(92.5)\end{array}$ & $\begin{array}{c}49 \\
(90.7)\end{array}$ & $\begin{array}{c}54 \\
(100)\end{array}$ & $\begin{array}{c}51 \\
(94.4)\end{array}$ & $\begin{array}{c}204 \\
(94.4)\end{array}$ \\
\hline \begin{tabular}{|c} 
Daily disinfected \\
of bins with $1 \%$ \\
hypochlorite \\
solution \\
\end{tabular} & 0 & $\begin{array}{c}50 \\
(92.59)\end{array}$ & $\begin{array}{c}54 \\
(100)\end{array}$ & $\begin{array}{c}54 \\
(100)\end{array}$ & $\begin{array}{c}158 \\
(73.14)\end{array}$ \\
\hline Collected daily & $\begin{array}{c}54 \\
(100) \\
\end{array}$ & $\begin{array}{c}54 \\
(100) \\
\end{array}$ & $\begin{array}{c}54 \\
(100)\end{array}$ & $\begin{array}{c}54 \\
(100)\end{array}$ & $54(100)$ \\
\hline \multicolumn{6}{|c|}{$\begin{array}{c}\text { Table 1. Observation of Colour Coded Bins at the Level of } \\
\text { Segregation }\end{array}$} \\
\hline
\end{tabular}

Table No. 1 showed that $95.37 \%$ bins were located at the right place, only $6.4 \%$ were placed on stand, $77.31 \%$ contained only infected waste. $96.2 \%$ of blue/ white bins and $90.7 \%$ of yellow bins were correctly located. $12.9 \%$ blue/ white bins were placed on stand. All the bags $(100 \%)$ were collected daily. $94.4 \%$ bags were correctly labelled, $2.77 \%$ bags were closed with fitting cover and only $73.14 \%$ bags were disinfected with $1 \%$ hypochlorite solution. Red bags were sufficiently (100\%) available, while only $90.7 \%$ yellow bags were available.

\begin{tabular}{|c|c|c|c|}
\hline $\begin{array}{c}\text { Personal } \\
\text { Clothing } \\
\text { Measures }\end{array}$ & $\begin{array}{c}\text { Doctors } \\
\text { (n/\%) }\end{array}$ & $\begin{array}{c}\text { Nurses } \\
\text { (n/\%) }\end{array}$ & $\begin{array}{c}\text { Grade IV } \\
\text { Workers } \\
\text { (n/\%) }\end{array}$ \\
\hline Gloves & $46(100)$ & $46(100)$ & $46(100)$ \\
\hline Masks & $30(65.21)$ & $43(93.47)$ & $42(91.30)$ \\
\hline Eye Shield & $12(26)$ & 0 & 0 \\
\hline Gumboots & 0 & 0 & $42(91.30)$ \\
\hline Aprons & $46(100)$ & $46(100)$ & $30(65.21)$ \\
\hline Table 2. Showing Personal Protective Measures worn by \\
Waste Handlers/ Health Care Workers \\
\hline
\end{tabular}

Table No. 2 showed that all the health care personnel used gloves $100 \%, 91.30 \%$ of grade IV workers used gumboots, $26 \%$ doctors used eye shields, $65.21 \%$ grade IV workers used aprons whereas $100 \%$ by doctors and nurses; $65.21 \%$ doctors, $93.47 \%$ nurses and $91.3 \%$ grade IV workers used masks.

\begin{tabular}{|c|c|c|c|c|}
\hline $\begin{array}{l}\text { Training and } \\
\text { Other } \\
\text { Particulars }\end{array}$ & $\begin{array}{c}\text { Doctors } \\
(46) \\
\text { No. (\%) }\end{array}$ & $\begin{array}{c}\text { Nurses } \\
(46) \\
\text { No. (\%) }\end{array}$ & $\begin{array}{c}\text { Grade IV } \\
\text { Workers } \\
(46) \\
\text { No. }(\%) \\
\end{array}$ & $\begin{array}{c}\text { Total No. } \\
(\%) \\
(138)\end{array}$ \\
\hline \begin{tabular}{|c|} 
Received any \\
training in \\
biomedical waste \\
handling \\
\end{tabular} & $\begin{array}{c}35 \\
(76.08)\end{array}$ & $\begin{array}{c}25 \\
(54.34)\end{array}$ & $\begin{array}{c}27 \\
(58.7)\end{array}$ & $\begin{array}{c}87 \\
(63.04)\end{array}$ \\
\hline \begin{tabular}{|c|} 
Sensitisation \\
workshop on \\
BMW \\
management \\
before/ joining \\
in service \\
\end{tabular} & $\begin{array}{c}35 \\
(76.08)\end{array}$ & $\begin{array}{c}25 \\
(54.34)\end{array}$ & $\begin{array}{c}27 \\
(58.7)\end{array}$ & $\begin{array}{c}87 \\
(63.04)\end{array}$ \\
\hline \begin{tabular}{|c|} 
Aware of risk \\
involved in BMW \\
handling
\end{tabular} & $\begin{array}{c}45 \\
(97.8)\end{array}$ & $\begin{array}{c}45 \\
(97.8)\end{array}$ & $\begin{array}{c}44 \\
(95.6)\end{array}$ & $\begin{array}{c}134 \\
(97.1)\end{array}$ \\
\hline $\begin{array}{l}\text { Hepatitis B } \\
\text { vaccination } \\
\text { received }\end{array}$ & $\begin{array}{c}45 \\
(97.8)\end{array}$ & $\begin{array}{c}45 \\
(97.8)\end{array}$ & $\begin{array}{c}14 \\
(30.4)\end{array}$ & $\begin{array}{c}104 \\
(75.36)\end{array}$ \\
\hline \begin{tabular}{|c|} 
Any injury/ \\
infection in past \\
6 months \\
\end{tabular} & 0 & 0 & 0 & 0 \\
\hline \begin{tabular}{|c|} 
Accidents \\
reported to \\
higher authority
\end{tabular} & 0 & 0 & 0 & 0 \\
\hline
\end{tabular}

Table No. 3 showed that only 87 (63.04\%) health care personnel had received training on biomedical waste handling and $97.1 \%$ had awareness about risk involved in BMW handling. The hepatitis B vaccine received only $75.36 \%$ 
by the health care workers. There was no history of injury reported to the higher authority in the health care facility.

\begin{tabular}{|c|c|c|}
\hline Observation & Yes & No \\
\hline $\begin{array}{c}\text { Trolley used for transportation of BMW } \\
\text { separately }\end{array}$ & Yes & - \\
\hline $\begin{array}{c}\text { Separate room/ area for storing waste after } \\
\text { collection }\end{array}$ & Yes & \\
\hline Separate route for transportation of BMW & - & No \\
\hline Waste not stored for more than 48 hrs. & Yes & \\
\hline $\begin{array}{c}\text { Weighing machine present in storage room/ } \\
\text { plant }\end{array}$ & Yes & \\
\hline \multicolumn{2}{|c|}{ Table 4. Observation at Level of Transportation } \\
and Storage Facilities of BMW
\end{tabular}

Table No. 4 shows that there were separate trolleys used for transportation of BMW at the health care facility. Also observed that the BMW was not stored for more than $48 \mathrm{hrs}$. There was no separate route for transportation of BMW.

\begin{tabular}{|c|c|c|c|c|}
\hline \begin{tabular}{|c|} 
Correct Knowledge \\
Regarding Biomedical \\
Waste \\
\end{tabular} & $\begin{array}{c}\text { Doctors } \\
(\mathrm{n} / \%)\end{array}$ & $\begin{array}{c}\text { Nurses } \\
(n / \%)\end{array}$ & \begin{tabular}{|c|} 
Grade IV \\
Workers \\
(n/\%) \\
\end{tabular} & \begin{tabular}{|c|} 
Total \\
No. \\
and \%
\end{tabular} \\
\hline $\begin{array}{l}\text { Is there } \\
\text { legislatio } \\
\text { managem }\end{array}$ & $\begin{array}{r}4 \\
(97\end{array}$ & $\begin{array}{c}45 \\
(97.8)\end{array}$ & $\begin{array}{c}44 \\
(95.6)\end{array}$ & \begin{tabular}{|c|}
134 \\
$(97.1)$
\end{tabular} \\
\hline $\begin{array}{r}\text { Colour codin } \\
\text { disp }\end{array}$ & & & & \\
\hline $\begin{array}{r}\text { Knowle } \\
\text { BMW } \\
\text { adequat } \\
\end{array}$ & $\begin{array}{c}46 \\
(100)\end{array}$ & $\begin{array}{c}46 \\
(100)\end{array}$ & $\begin{array}{c}46 \\
(100)\end{array}$ & $\begin{array}{c}138 \\
(100)\end{array}$ \\
\hline $\begin{array}{r}\text { Segrega } \\
0 \\
\end{array}$ & $\begin{array}{r}4 \\
(9) \\
\end{array}$ & $(9$ & $\begin{array}{r}4 \\
(95 \\
\end{array}$ & \begin{tabular}{|c|}
134 \\
$(97.1)$
\end{tabular} \\
\hline \begin{tabular}{|r|} 
Storage \\
$(\mathrm{d}$ \\
\end{tabular} & & 20 & $\begin{array}{c}44 \\
(95.6) \\
\end{array}$ & $\begin{array}{c}97 \\
(70.2) \\
\end{array}$ \\
\hline $\begin{array}{l}\text { Diseas } \\
\text { throug } \\
\text { B/C/tet }\end{array}$ & $\begin{array}{r}46 \\
(10\end{array}$ & $(86.95)$ & $\begin{array}{c}20 \\
(43.47)\end{array}$ & $(76.81)$ \\
\hline $\begin{array}{c}\text { Identification of } \\
\text { biohazard symbol }\end{array}$ & $\begin{array}{c}46 \\
(100) \\
\end{array}$ & $\begin{array}{c}45 \\
(97.8) \\
\end{array}$ & $\begin{array}{c}45 \\
(97.8) \\
\end{array}$ & \begin{tabular}{|c|}
136 \\
$(98.55)$ \\
\end{tabular} \\
\hline \multicolumn{5}{|c|}{$\begin{array}{c}\text { Table 5. Knowledge regarding Biomedical Waste among } \\
\text { the Health Care Workers }\end{array}$} \\
\hline
\end{tabular}

Table No. 5- The table showed that the knowledge on legislation for BMW management in India was found to be $97.1 \%$ among health care workers and found to be satisfactory. The knowledge on colour coding for waste disposal and segregation at source of BMW was $97.1 \%$, on storage of BMW waste duration $70.2 \%$, on disease transmission $43.47 \%$ among grade IV workers and $86.95 \%$ among nurses. On biohazard symbol, $97.8 \%$ among nurses and grade IV workers.

\section{DISCUSSION}

In the present study conducted at tertiary care hospital, 138 health care personnel were included from the various departments, wards, OTs, ICUs, OPDs, casualty department, blood banks etc. In the study, we found that the blue/ white bags were located (100\%) and yellow bags (90.7\%), 12.9\% (blue/white) bags were correctly placed on stand, but Srivastav et $\mathrm{al}^{6}$ found that the colour-coded bins were not placed on stand as well as closed fitting covers on them were missing in majority of wards. About the availability of red bags $(100 \%)$ and yellow bags $(90.7 \%$ were observed and $94.4 \%$ of the bins were correctly labelled. In the study done by Ismail IM7 et al, observed that only one-third of the study participants used the colour coded system. Muluken A et al (2011) ${ }^{8}$ found that only $31.9 \%$ of health care workers segregated wastes by their type with the available dust bins. In this study, wastes were collected daily and transported to the designated central storage sites. For transportation of wastes from collected sites, mostly wheeled trolley was used by the health workers. But in a study conducted by Umar Rn $\mathrm{AB}$ et $\mathrm{al}^{9}$ found that collection of hospital waste using bare hands by the hospital cleaners and infectious wastes were not labelled by biohazard symbols. These might be due to lack of awareness as well as poor implementation of policies and management of biomedical waste management in those areas. The knowledge regarding biomedical waste management among the health care were found to be satisfactory in this study (100\%), where $90 \%$ among doctors was found by Ismail IM. Most of the health care workers used the personal protective measures except eye shields (26\%) by doctors and gumboots (91\%) by grade IV workers. In a study conducted by Shyamala R $(2016)^{10}$ found that only $88 \%$ of the health care workers used protective measures to prevent health hazards. Pandit NB et al (2005) ${ }^{11}$ found that lack of knowledge about waste management among doctors, which affects the safe practices for management. In a study conducted in Iran in the University Hospitals of Fars Province also found insufficient training of health personnel, insufficient personal protective measures and lack of knowledge regarding the proper use of such equipment. The training on biomedical waste among the healthcare were $(63.04 \%)$ unsatisfactory in this study. So, periodic training as well as sensitisation workshop on biomedical waste management must be done by the health care workers. In a study done by Muluken A et al (2011) ${ }^{8}$ in Northwest Ethiopia, also found only $53.1 \%$ of health care personnel had training on biomedical waste management. In another study conducted by Srivastav S et al (2009), 6 found only $14 \%$ by Dohare S et al ${ }^{12}(4.2 \%)$ in 2007 - 2008 by Ananthachari K et al (2016) $29.8 \%$ only ${ }^{13}$ among health care workers received training on BMW management. By Ismail IM et al found none of the health care personnel were trained on biomedical waste. In this study, the knowledge on biomedical rules/ legislation among health care personnel were found to be $97.1 \%$, whereas in a study done by Sharma A et $\mathrm{al}^{14}$ found to be $36 \%$ among nurses. But in a study conducted in New Delhi in 2000,15 reported that majority of the study participants were not aware of the proper clinical waste management regulations. Similar findings reported by Sharma et al (2010), ${ }^{16}$ which indicated a lack of knowledge and awareness towards legislation on BMW. In the present study, 97.1\% health care workers had awareness regarding risks associated with biomedical waste, but in a study done by Pandit NB et al (2005) found 30\%,10\% by Srivastava S et al (2009), by Mathur V et al ${ }^{17} 27 \%$ and Bansal M et al 18 43\%. The knowledge on colour coding of bags for waste disposal was found to be $97.1 \%$ among health care workers in present study, by Sharma $\mathrm{N}$ et $\mathrm{al}^{19}$ in their study at Jabalpur found that $95 \%$ were aware of the colour coding for waste segregation but did not have any clear idea of what should be disposed in which bin. Basu $\mathrm{M}$ et al20 mentioned that only $76.4 \%$ and Ismail MI $35.5 \%{ }^{8} \mathrm{knew}$ about various types of 
colour coded bags for collection of biomedical waste. The knowledge about BMW storage duration in this study was found to be $50 \%$ among doctors, $65.21 \%$ among nurses, $95.6 \%$ among grade IV workers in comparison with a study by Anand $\mathrm{P}$ found to be as $54.2 \%$ among doctors, $36.4 \%$ nurses and $13.3 \%$ among grade IV workers and $36.6 \%, 70 \%$ and $30 \%$ by Ismail MI 8 in his study. In the present study, only $30.40 \%$ of grade IV workers were found to be vaccinated with hepatitis B vaccine. This may be due to lack of awareness of the health care workers and proper information to the health authorities. A study done by Deb A $2016^{21}$ found $88.6 \%$ of intern doctors were vaccinated with hepatitis B and $100 \%$ with Tetanus and by Ananthachari KR et al ${ }^{13}$ found $70.7 \%$ with hepatitis B. In the present study, there was no history of injury recorded following handling of bio-medical waste. Similar findings also reported by Dohare S et al ${ }^{12}$ (2007 2008) in their study. Injury reporting due to sharps by Mathur et al found to be $60 \%$ among doctors and Stein et al 22 found to be $37 \%$ in their study population. In the present study, the knowledge on BMW storage time among nurses were found to be $65.21 \%$ in comparison to $39.36 \%$ by Balamurugan SS et $\mathrm{al}^{23}$ in their study. ${ }^{16}$ The knowledge about the diseases transmitted through BMW was highest (100\%) among doctors, $86.95 \%$ among nurses and $43.47 \%$ among grade IV workers in our study. Similar findings were also reported by Anand $\mathrm{P}$ et al 24 of about $91.6 \%$ by doctors, $81.8 \%$ by nurses and $41.6 \%$ by grade IV workers. The knowledge on biohazard symbol was found to be $100 \%$ by doctors, $97.8 \%$ among nurses and grade IV workers in our study, whereas by Anand $\mathrm{P}$ et al reported to be $87.5 \%$ among doctors, $52.7 \%$ nurses and $20 \%$ by grade IV workers.

\section{CONCLUSION}

The study concluded that the biomedical waste management practices and knowledge among the health care personnel were found to be average.

\section{Recommendations}

1. The guidelines on BMW Rules 2016 should be available to health care facilities.

2. Training on BMW of the health care workers should be strengthened.

3. The immunisation coverage to all health care workers should be done.

4. To maintain coordination with local municipality for non-hazardous waste handling in order to reduce waste load.

5. There must be strict supervision and surveillance of hospital waste management activities by the hospital authorities.

The main strengths of our study are as follows. We found that the knowledge regarding availability of manual/ guidelines and plan is $100 \%$ among all healthcare workers. $97.1 \%$ of the healthcare workers were found to have knowledge about the hazardous wastes and risks involved in handling such wastes, while the knowledge among grade IV workers was $95.6 \%, 97.1 \%$ health care workers practiced segregation of waste at source which is also another important point and lastly $97.1 \%$ of health care workers were aware of biohazard symbol. The limitations of our study are 1. limited time period. 2 . Findings may not be generalised to the whole population since purposive sampling was done. 3 . details of vaccination coverage was not fully found by the health care workers 4. sensitisation workshops on BMW management had received response from only $63.04 \%$ of healthcare workers.

\section{ACKNOWLEDGEMENT}

Like to acknowledge the study participants for their cooperation during the study as well as the UG students for their constant support during this research work.

\section{REFERENCES}

[1] Government of India. Biomedical Waste (Management and Handling Rules. 1998, extraordinary, Part II, Section 3, Subsection (ii). The gazette of India, No, 460, 27 Jul 1998).

[2] Suryakantha AH. Management of hospital waste. In: Suryakantha AH, edr. Community medicine with recent advances. $4^{\text {th }}$ edn. India: The Health Science Publisher 2017: p. 93-107.

[3] Park K. Hospital waste management. In: Park's textbook of preventive and social medicine. $22^{\text {nd }}$ edn. Jabalpur, India: Banarsidas Bhanot Publishers 2013: p. 734-9.

[4] Kishore J, Ingle GK. Biomedical waste management in India. $1^{\text {st }}$ edn. New Delhi: Century Publishers 2004: p. 1.

[5] Annual Report 2017. 71 ${ }^{\text {st }}$ College Foundation Day. Assam Medical College \& Hospital, Dibrugarh, Assam. 2017.

[6] Srivastav S, Mahajan H, Mathur BP. Evaluation of biomedical waste management practices in a government medical college and hospital. National J Community Medicine 2012;3(1):82-4.

[7] Ismail IM, Kulkarni AG, Kamble SV, et al. Knowledge, attitude and practice about bio-medical waste management among personnel of a tertiary health care institute in Dakshina Kannada, Karnataka. Al Ameen J Med Sci 2013;6(4):376-80.

[8] Azage M, Gebrehiwot H, Mesafint M. Healthcare waste management practices among healthcare workers in healthcare facilities of Gonder town, Northwest Ethiopia. Health Science J 2013;7(3):315-26.

[9] Umar Rn AB, Yahaya NM. Hospital waste management practices: a case study of primary health care Centers, in Fagge local Government area, Kano State. J of Nursing \& Health Sci 2014;3(6):26-33.

[10] Shyamala R, Naveen G. A cross-sectional study on health care waste management among health care personnel in a tertiary care Center, Kannur, Kerala, India. Int J Curr Microbiol App Sci 2016;5(9);340-5.

[11] Pandit NB, Mehta HK, Kartha GP, et al. Management of bio-medical waste: awareness and practices in a district of Gujarat. Indian Journal of Public Health 2005;49(4):245-7.

[12] Dohare S, Garg VK, Sarkar BK. A study of hospital waste management status in health facilities of an urban area. Int J Pharma Bio Sci 2013;4(1):(B)1107112. 
[13] Ananthachari KR, Divya CV. A study on assessment of knowledge on biomedical waste management among health care workers of Malabar Medical College Teaching Hospital, Calicut, Kerala, India. Int J Community Medicine \& Public Health 2016;3(9):240913.

[14] Sharma A, Sharma V, Sharma S, et al. Awareness of biomedical waste management among health care personnel in Jaipur, India. Oral Health Dent Manag 2013;12(1):32-40.

[15] Kishore J, Goel P, Sagar B, et al. Awareness about biomedical waste management and infection control among dentists of a teaching hospital in New Delhi, India. Indian J Dent Res 2000;11(4):157-61.

[16] Sharma S. Awareness about bio-medical waste management among health care personnel of some important medical centres in Agra. IJESD 2010;1:25155.

[17] Mathur V, Dwibedi S, Hassan MA, et al. Knowledge, attitude and practices about bio-medical waste management among healthcare personnel: a crosssectional study. Indian $\mathrm{J}$ of Community Medicine 2011;36(2):143-5.

[18] Bansal M, Mishra A, Gautam P, et al. Bio-medical waste management: awareness and practices in a district of Madhya Pradesh. National J of Community Medicine 2011;2(3):452-6.
[19] Sharma N, Devi KS. Study about awareness and practices of healthcare waste management among Medical practitioners and hospital staff in a Medical College Hospital, Jabalpur. JMSCR 2017;5(3):18890-5.

[20] Basu M, Das P, Pal R. Assessment of future physicians on biomedical waste management in a tertiary care hospital of West Bengal. J Nat Sci Biol Med 2012;3(1):38-42.

[21] Deb A, Gajbhiye S, Raut S. Awareness about biomedical waste management amongst medical interns an interventional study from Central India. JEMDS 2017;16(16):1256-9.

[22] Stein AD, Makarawo TP, Ahmed MF. A survey of doctor's and nurse's knowledge, attitudes and compliance with infection control guidelines in Birmingham teaching hospital. J Hosp Infect 2003;54(1):68-73.

[23] Balamurugan SS, Priyadarsini SP, Renusha J, et al. A descriptive study on knowledge regarding biomedical waste management among health care personnel in a tertiary care hospital. National Journal of Research in Community Medicine 2014;3(2):186-91.

[24] Anand P, Jain R, Dhayani A. Knowledge, attitude and practice of biomedical waste management among health care personnel in a teaching institution in Haryana, India. Int J Res Med Sci 2016;4(10):4246-50. 